\title{
Sex and quacks in the 18th century
}

\author{
Lesley Smith
}

\section{Introduction}

It is unusual for me as a medical historian to stray far away from my specialist area, the 16th century, but for this article I could not resist sharing the phantasmagorical glories of quack treatment as 'cures' for sexual difficulties - they are just too wonderful!

\section{8th century society}

The 18th century was a very exciting time. Science was hugely fashionable, the Lunar Society of Birmingham (established by the likes of Josiah Wedgwood, Joseph Priestly, James Watt and Erasmus Darwin) had made its mark and the 'Age of Enlightenment' was upon us. In 1794, Erasmus Darwin of Lichfield (physician, poet, philosopher, botanist and inventor - one of the leading intellectuals of 18th century England and the grandfather of Charles Darwin) published Zoomania (or the Laws of Organic Life) in which he expressed his evolutionary concepts and medical philosophy in verse, whilst taking a little time out to examine cadavers in his cellar. His neighbours and friends, Garrick and Dr Johnson (of dictionary fame) would have no doubt joined Darwin to observe over a glass of canary (a type of sherry). This is the time of mummy unwrapping parties when the powerful and wealthy would invite friends round for a buffet served in a room where a doctor unwrapped a mummy brought back to England by early Egyptologists.

Many believed the shackles of the early Church were struck away by the new scientists, and agnostics and atheists were no longer burned at the stake as heretics. These new thinkers were, however, often metaphorically burned in the press. The presses were also busy with the huge rise in production of erotic literature, which flooded the streets or could be bought discreetly for as much as a guinea by those with experimental taste. Some of the literature in pictures and text would be viewed as explosive even today. Sadomasochism, buggery and even bestiality feature. Many of us read Justine as students but little prepares us for the Marquis de Sade (1740-1814). Despite its claims to strike away sexual restraint, the work also has a darkness about it that is positively chilling even to a hardened sexual health historian like me.

Liberal behaviour was accepted across most of the century dominated by the German kings, many of whom still had mistresses who featured largely (literally in some cases) in many levels of society.

It seems there were forms of sexual equality, as women frequently took lovers once they had produced an 'heir and a spare'. As each individual divorce still had to be debated in Parliament, many couples found it easier to live apart and were not necessarily rejected from polite company.

Satins, velvets and embroidery blazed in rainbow colours and wigs were high dressed and powdered white. Painted faces, coral cheeks and mouths spoke of excess and whole family fortunes could be lost at the turning of a card. Homosexuality was so fashionable as a style that men feigned homosexual behaviour in speech and style - what we might describe today as 'camp'.

J Fam Plann Reprod Health Care 2008; 34(1): 63-64

Tutbury Castle, Tutbury, UK

Lesley Smith, Curator

Correspondence to: Lesley Smith, Tutbury Castle, Tutbury, Staffordshire DE13 9JF, UK. E-mail: info@tutburycastle.com

\section{Quacks and charlatans}

New sciences, including medicine, were all the rage, particularly as the skills of a physician or quack often claimed to enhance looks, longevity or sexual performance. 'Quacks and charlatans' came into great prominence at this time, having their own class-system culture.

At the top of the pile were the 'once went to medical school' quacks and experimental 'scientists', some of whom commanded fees higher than those charged by qualified physicians.

In the middle, there were commercial preparation manufacturers who would produce anything from tooth powders to cancer cures, making wild claims in advertisements and leaflets. The great joy of reading these publications is their pseudoscientific language, which to the untrained eye might be impressive. To the modern observer, however, they are hilarious, and include such gems as the advertisements run by one quack for his wondrous pills which "operate seven several ways viz. Hypnotically, Hydrotically, Carthartically, Proppysinatically, Hydragogically, Pulmatically and lastly Synecdochially by corroborating the whole Oeconmia Aanimalis" (from Quacks of Old London).

Finally, there was the showman with his portable table, open case and fake patient who would leap from a crowd, claiming that this man had healed her when she was on the edge of death. The bottle of health salvation for sale would likely be something like tar water or worse. However, it is interesting to see that many of the compounds for sale, whatever class strata the quacks came from, were usually useless and often dangerous.

There was a great curiosity and awakening of interest in science generally when John Taylor, who had enjoyed some training at St Thomas's Hospital, gave lectures. He would wear a dramatic costume of black and bright red and address his audience of up to 300 individuals from a stage. The quacks certainly knew how to put on a show, and although there are court cases and endless newspaper attacks from trained physicians, their audiences still flooded in.

\section{Sexual/reproductive health remedies}

Commercial gynaecological 'medicines' were sold on the streets. Preparations promised to remove "female obstructions" and "repulse courses". Delay in menarche could also be resolved by "medical waters". If "medical waters" sounds unlikely, how about "medical music", known to have been offered to rapt audiences at hugely high prices in "medical theatres". These theatres offered performances that the promoters claimed could cure impotence or infertility. Graham was an early sex therapist, a half-trained medicine man, who ran the "Temple of Hymen" in London. Magnetoelectricity was a favourite cure-all of 'Dr' Graham via various galvanic therapies. The ending of some of his sessions would be heralded by an unexpected electric shock passed through the seats of the guests. Startled cries and leaping about were observed, with many believing this mighty tingle would regenerate the sexual organs into life again. One doesn't have to be a psychologist to realise that these treatments often did assist with some form of impotence and therefore testimonies of success were sometimes genuine.

Women who did not conceive were very often considered the guilty party and a quasi-medical range of poisonous potions including steaming and mercury treatments were offered to cleanse and regenerate sexual organs. 
Women and men who masturbated were viewed as wasting their bodies and weakening their chances both of conception and carrying a fetus to full term. The idea of connecting poor eyesight and masturbation was published for the first time around this period, as far as I can tell, along with weak teeth, back pain and stooping shoulders.

Man-midwives, known as early as the 17 th century, are by the 18th century even publishing advice books and helping directly with the birthing process. Midwives generally seemed to escape the worst insults thrown at quacks, but there are cases of witchcraft accusations even at this late time.

Contraception is written about as gut condoms, citrus fruit tops and abortion. Gynaecological health was dominated by sexually transmitted diseases, now rampant through all levels of society.

\section{Concluding remarks}

This article can only hope to give a hint of the hilarious range of treatments on offer during this period of history. What one can see, however, amongst the insane and desperate remedies of the time, are glimmers of the thinkers and the scientists we know today, like a light on the horizon.

\section{Future articles}

The next article in this series will be on the controversial topic of Mary Stuart's miscarriage.

\section{Author's note}

In my last article I asked if readers had knowledge of any published information they may have seen relating to female chastity belts. I would like to take this opportunity of thanking all of you who took the trouble to write to me with glimmers of information and some mind-boggling current designs for chastity belts. However, we still have no historical evidence of chastity belts for women.
Acknowledgements

The author would like to thank the following individuals for their help and advice: Professor R Arnott, Director of the Centre for the History of Medicine, University of Birmingham Medical School, Birmingham and Dr G Williams, Curator of the British Museum, London, UK.

Bibliography

1 Porter, Roy. Quacks: Fakers \& Charlatans in Medicine. Stroud, UK: Tempus Publishing Ltd, 2003.

2 Thompson, Charles JS. Quacks of Old London (first published in 1928) Whitefish, MT, USA: Kessinger Publishing, 2003.

3 Hamilton, David. The Healers. Edinburgh, UK: Canongate Publishing Ltd, 1981.

4 Sloan, AW. English Medicine in the Seventeenth Century. Bishop Auckland, UK: Durham Academic Press, 1996.

5 Driver, Christopher and Berriedale-Johnson, Michelle. Pepys at Table. London, UK: Bell \& Hyman, 1984.

6 Herman, Eleanor. Sex with Kings: Five Hundred Years of Adultery, Power, Rivalry, and Revenge. London, UK: Harper Perennial, 2005.

7 Aristotle's Masterpiece (a manual of sex and pregnancy) Unknown author and publisher, circa 1684. (NB. Copies of this book can be found in antiquarian bookshops. Some of the later editions are reasonably priced but the earlier editions with little editing are much more fascinating.)

8 Berry, George. Taverns and Tokens of Pepys' London. London, UK: Seaby Publications Ltd, 1978.

9 Wilson, Derek. All the King's Women: Love, Sex and Politics in the Life of Charles II. London, UK: Pimlico, 2004.

10 Prior, Mary (ed.). Women in English Society 1500-1800. London, UK: Routledge, 1985.

About the author

Lesley Smith is a late-16th century historian, currently studying for the degree of MPhil in the History of Medicine at Birmingham University Medical School (and waiting to see if her proposal will be accepted as a PhD). During 2007 Lesley has appeared in television programmes on the east and west coasts of America, Transylvania and England. She is currently advising on a Tudor documentary for the BBC as a medical historian. She has also recently joined the debate on BBC radio about legalisation of brothels - a debate stimulated by the National Federation of Women's Institutes.

\section{Raising interest in Contraception and Sexual Health: Special Study Modules for medical students}

\section{Christina Fey, Chloe Evans}

\section{The problem}

Getting the balance correct in medical workforce planning, particularly in Obstetrics and Gynaecology (O\&G), has been a problem for a number of years. Over the last 10 years, training numbers have varied and the balance between trainees qualified and number of consultant posts available has wavered. Bearing in mind the Government's aims for a consultant-delivered service, and the need for future increase in senior posts (another discussion entirely

J Fam Plann Reprod Health Care 2008; 34(1): 64-65 (Accepted 14 February 2007)

Derby City PCT, Department of Contraception and Sexual Health, Wilderslowe, Derby, UK

Christina Mary Fey, MBChB, MRCOG, Consultant

University of Nottingham Medical School, Faculty of Medicine and Health Services, Queens Medical Centre, Nottingham, UK Chloe Miranda Evans, PhD, Medical Student

Correspondence to: Dr Christina Fey, Derby City Primary Care Trust, Department of Contraception and Sexual Health, Wilderslowe, 121 Osmaston Road, Derby, Derbyshire DE1 2GA, UK. E-mail: christina.fey@derbycitypct.nhs.uk around consultants vs non-consultant senior grade!), we are now seeing the possibility of failure to provide enough trainees to fill anticipated posts. In particular, there are notably fewer trainees attracted to $O \& G$, and we see parallel problems in recruiting to Contraception and Sexual Health (C\&SH). Even now we have unfilled consultant and trainee posts throughout the country (see Workforce Planning Committee reports) $)^{1,2}$ and attracting trainees to our speciality remains a challenge.

A recent survey in the British Journal of Obstetrics and Gynaecology ${ }^{3}$ looked at the main career choices made by medical students and newly qualified doctors and ascertained what factors influenced choice of career. In the first year after graduation the most important factors were experience of their chosen subject as a student, a particular teacher or department, and a doctor's enthusiasm for, and commitment to, the speciality. There were also noticeable differences between different medical schools and choices of career.

Higham, in another article in the same journal, noted changes in medical school curriculum planning over the last 15 years. ${ }^{4}$ There is less time dedicated to O\&G and a teaching block is often shared with other related 